\title{
PREVALENCE OF MALNUTRITION RISK AMONG INSTITUTIONALIZED ELDERLY FROM NORTH BOHEMIA IS HIGHER THAN AMONG THOSE IN THE CAPITAL CITY OF PRAGUE, CZECH REPUBLIC
}

\author{
Miroslava Slavíková1, Bohumír Procházka², Pavel Dlouhý1, Michal Anděl', Jolana Rambousková1 \\ ${ }^{1}$ Centre for Research of Nutrition, Metabolism and Diabetes, Department of Hygiene, Third Faculty of Medicine, Charles University, Prague, \\ Czech Republic \\ ${ }^{2}$ Department of Statistics and Informatics, National Institute of Public Health, Prague, Czech Republic
}

\section{SUMMARY}

Objective: The aim of the study is to assess the risk of malnutrition among institutionalized elderly individuals in North Bohemia and compare it to the risk of malnutrition in the capital city of Prague, Czech Republic. In the Czech Republic, very few studies have been conducted with the goal of describing and evaluating the nutritional status of the institutionalized elderly.

Methods: In this study, data was collected from 254 elderly individuals (aged $\geq 65$ ) residing in retirement homes in North Bohemia and then compared with similar data for the elderly living in retirement homes in Prague (the data from Prague were previously published in 2013). The data included an Mini-Nutritional Assessment (MNA) test; anthropometric measurements - Body Mass Index (BMI), waist circumference, triceps skinfold thickness; and biochemical parameters - albumin, prealbumin, transferrin, urea, and creatinine.

Results: Mean BMI values were $27.4 \mathrm{~kg} / \mathrm{m}^{2}$ for females and $26.3 \mathrm{~kg} / \mathrm{m}^{2}$ for males. According to the MNA questionnaire, $10.4 \%$ of all tested elderly were malnourished and $50.8 \%$ were at risk of malnutrition; lager proportion of females were found to be malnourished than males. Biochemical indicators supported the MNA results. MNA categories correlated positively with independence $(r=0.56 ; p<0.001)$, mental status $(r=0.54 ; p<0.001)$, mobility ( $r=0.46 ; p<0.001)$, calf circumference $(r=0.42 ; p<0.001)$, BMl, and the ability to self-feed (both $r=0.37 ; p<0.001)$. The percentage of institutionalized elderly with malnutrition living in North Bohemia and Prague were about the same; however, the percentage of those at risk of malnutrition was higher in North Bohemia $(p=0.006)$.

Conclusion: Study results confirmed that the institutionalized elderly face issues that lower their nutritional status and put them at increased risk; clearly these issues need urgent attention.

Key words: institutionalized elderly, malnutrition, mini-nutritional assessment, nutritional status

Address for correspondence: M. Slaviková, Centre for Research of Diabetes, Metabolism and Nutrition, Department of Nutrition, Third Faculty of Medicine, Charles University, Ruská 87, 10000 Prague 10, Czech Republic. E-mail: slavikovamiroslava@seznam.cz

https://doi.org/10.21101/cejph.a4944

\section{INTRODUCTION}

The quality of daily nutrition has a significant impact on the overall health of an individual. Malnutrition is caused by an inadequate intake of nutrients, (often protein) and is frequently associated with a deterioration of health status or worsening of pre-existing conditions (1). Nutrition quality is important throughout life; however, it is particularly important when it affects vulnerable population groups (e.g., children, elderly, pregnant women). Seniors, who are often already frail, belong to a group that is at particular risk. Nutrition has a considerable impact on the ageing process and, conversely, the ageing process has considerable impact on the nutritional needs of an individual, therefore, good nutrition becomes a basic element of geriatric health. Analyses indicate that malnutrition is associated with a number of geriatric conditions (2). Additionally, malnutrition can significantly impact the overall health of the elderly. The prevalence of malnutrition in the non-institutionalized elderly ranges from 5-20\% across most European countries (3), however, it rises to $30-85 \%$ for the institutionalized elderly, i.e., those living in nursing homes or those that are hospitalized (3). Other studies have shown that the prevalence of malnutrition in seniors that are non-institutionalized and living on their own is relatively low (0-10\%) (4). In a German study, the prevalence of malnutrition in the non-institutionalized elderly was only $2 \%$, although the percentage of those at risk of malnutrition was $24 \%$ (range 8-76\%) (5). Colombia provides another good example, where only $4.6 \%$ of the non-institutionalized elderly were malnourished, but again, the number at risk of malnutrition (34\%) was high (6). In a Norwegian study, more than $60 \%$ of the institutionalized elderly population was found to be malnourished upon admittance to urgent care facilities or hospitals (7). Considering demographic development and the expected continued rise in the elderly population, there is a strong need for studies focused on the description, diagnosis and resolution of malnutrition in the elderly, especially within nursing homes (8). 
Retirement homes in the Czech Republic primarily provide social services for elderly individuals with age-related decreases in self-sufficiency that require regular assistance. This study sought to explore regional differences in malnutrition. To that end, the elderly population in North Bohemia, which is more rural or industrial, and the elderly population of Prague, which is more urban and commercial, was compared. The abundance of natural resources (brown coal) has meant that coal and chemical industries in North Bohemia have been heavily developed since World War II. This development attracted large numbers of manual workers to the North Bohemia region. While Prague and other large cities tended to attract more office workers to fill the demand for administrative positions.

The aim of this study was to describe the nutritional status of the institutionalized elderly living in three North Bohemian towns and compare it with the nutritional status of the institutionalized elderly living in Prague. The published data are part of a larger project. The project also included blood analyses of seniors regarding levels of trace elements and heavy metals. Results from Prague's study were previously published in 2013 (9).

\section{MATERIALS AND METHODS}

\section{Subjects and Sampling Locations}

The study provides a description and evaluation of the nutritional status of the institutionalized elderly in three retirement homes in three different North Bohemian towns (Teplice, Most and Dubí). The sample comprised 254 participants (183 females and 71 males), who resided in retirement homes. Fifty percent of the residents living in each retirement home were examined. Inclusion criteria for the study restricted the sample to those aged at least 65 and without any acute illness or catabolic diseases, including cancer. Data was collected from each facility in cooperation with the head nurse, and information related to medical conditions and medications was obtained from personal medical histories.

\section{Mini-Nutritional Assessment, Anthropometry and Biochemistry}

A description of nutritional status was established using the following five parameters: measurement of anthropometric indicators - triceps skinfold thickness and waist circumference (WC); completion of the Mini-Nutritional Assessment (MNA) questionnaire; taking a nutritional history; questions regarding use of food (nutritional) supplements and type of diet, use of tobacco; and analysis of malnutrition biochemical markers. The full MNA questionnaire, which included 18 questions in 4 categories, was used in this study (10). The questionnaire included an anthropometric assessment - weight, height, weight loss, mid-arm circumference (MAC) and calf circumference (CC); a general assessment of e.g., lifestyle, medications, mobility, and presence of signs of dementia and depression; dietary assessment (number of meals per day, food, and fluid intake); and a self-assessment (self-perception of health and nutrition). The maximum possible MNA score was 30 points, a score of less than 17 points was used as an indicator of malnutrition. A score of 17 to 23.5 points was used as an indicator of patients who were at risk of malnutrition. Overnight fasting blood samples were collected for biochemical testing of serum proteins, urea and creatinine. Some respondents did not agree with blood collection and in some respondents blood collection was not possible. Therefore, the final group of biochemical blood analysis consists of 195 respondents only. The results were compared with established reference values, albumin $35.0-50.0 \mathrm{~g} / 1$, prealbumin $0.20-0.40 \mathrm{~g} / \mathrm{l}$, transferrin $2.00-4.00 \mathrm{~g} / \mathrm{l}$, urea $2.83-8.35 \mathrm{mmol} / \mathrm{l}$ and creatinine $71.0-133.0 \mu \mathrm{mol} / 1(11,12)$.

\section{Data Comparison}

The results of North Bohemia respondents were compared with the results of the Prague respondents. Prague elderly individuals were assessed using the same (previously described) protocol and included those aged $\geq 65$ years residing in retirement homes.

Table 1. Baseline anthropometric and health characteristics of institutionalized elderly participants from North Bohemia ( $N=254)$

\begin{tabular}{|l|c|c|c|}
\hline Characteristics & $\begin{array}{c}\text { Females } \\
\mathrm{n}=183\end{array}$ & $\begin{array}{c}\text { Males } \\
\mathrm{n}=71\end{array}$ & $\mathbf{p}^{3}$ \\
\hline Age $($ years) & \multicolumn{1}{|c|}{0.001} \\
\hline Weight $(\mathrm{kg})^{1}$ & $80.8(8.05)$ & $75.9(8.71)$ & 0.005 \\
\hline Height $(\mathrm{m})^{1}$ & $67.9(15.8)$ & $76.0(16.9)$ & 0.001 \\
\hline BMl $\left(\mathrm{kg} / \mathrm{m}^{2}\right)^{1}$ & $1.58(0.07)$ & $26.3(5.42)$ & $\mathrm{ns}$ \\
\hline Mid-arm circumference $(\mathrm{cm})^{1}$ & $27.4(5.95)$ & $28.5(3.77)$ & $\mathrm{ns}$ \\
\hline Calf circumference $(\mathrm{cm})^{1}$ & $28.5(4.39)$ & $34.8(4.04)$ & $\mathrm{ns}$ \\
\hline Triceps skinfold thickness $(\mathrm{mm})^{1}$ & $34.4(5.29)$ & $12.0(6.43)$ & 0.001 \\
\hline Waist circumference $(\mathrm{cm})^{1}$ & $16.5(6.5)$ & $102.9(13.6)$ & $\mathrm{ns}$ \\
\hline Ischaemic heart disease $(\%)^{2}$ & $98.0(13.4)$ & 50.7 & $\mathrm{~ns}$ \\
\hline Hypertension $(\%)^{2}$ & 49.5 & 43.7 & $\mathrm{~ns}$ \\
\hline Diabetes $(\%)^{2}$ & 61.5 & 29.6 & $\mathrm{~ns}$ \\
\hline Never smoked $(\%)^{2}$ & 34.1 & 54.3 & 0.001 \\
\hline Former smokers $(\%)^{2}$ & 80.1 & 21.4 & 0.001 \\
\hline Current smokers $(\%)^{2}$ & 8.3 & 24.3 & 0.001 \\
\hline
\end{tabular}

${ }^{1}$ Data are presented as mean (standard deviation), ${ }^{2}$ percentage of sample, ${ }^{3}$ significant differences between females and males, $\mathrm{ns}=\mathrm{not}$ significant 
Table 2. General characteristics of institutionalized elderly participants from North Bohemia $(N=254)$

\begin{tabular}{|c|c|c|c|}
\hline Characteristics & $\begin{array}{c}\text { Females } \\
n=183\end{array}$ & $\begin{array}{l}\text { Males } \\
n=71\end{array}$ & $\mathrm{p}$ \\
\hline \multicolumn{4}{|l|}{ Marital status (\%) } \\
\hline Single & 1.8 & 28.3 & \multirow{4}{*}{0.001} \\
\hline Married & 7.8 & 5.0 & \\
\hline Widow/widower & 81.4 & 48.3 & \\
\hline Divorced & 9.0 & 18.3 & \\
\hline \multicolumn{4}{|l|}{ Education (\%) } \\
\hline Primary school & 54.7 & 34.4 & \multirow{4}{*}{0.005} \\
\hline Vocational school $^{*}$ & 29.4 & 43.8 & \\
\hline Secondary school & 14.7 & 14.1 & \\
\hline University & 1.2 & 7.8 & \\
\hline \multicolumn{4}{|c|}{ Employment before retirement (\%) } \\
\hline Manual worker & 63.4 & 68.2 & \multirow{3}{*}{0.005} \\
\hline Office worker & 18.9 & 14.7 & \\
\hline Other & 17.7 & 17.1 & \\
\hline \multicolumn{4}{|c|}{ Entered retirement home from (\%) } \\
\hline Home & 65.6 & 63.2 & \multirow{3}{*}{ n.s. } \\
\hline Long-term hospital & 31.2 & 28.1 & \\
\hline Other healthcare facility & 3.2 & 8.8 & \\
\hline
\end{tabular}

ns $=$ not significant, ${ }^{*}$ trade or vocational school

\section{Statistical Analysis}

The results of comparison are presented as percentages, means and standard deviation (SD). The distribution of tested values was assumed to be normal, therefore, the Wilcoxon two-sample test was used. Additional statistical analyses included the Chisquared test of independence in contingency tables, as well as Fischer's exact test for contingency tables for comparison of groups. Inter-group differences and correlations were tested, and p-values less than 0.05 were accepted as statistically significant. All statistical analyses were performed using SPSS software for Windows (version 19.0).

\section{Ethical Considerations}

The study was performed according to the Helsinki declaration. Each participant was thoroughly informed about the study objectives and its methods, and each provided signed consent. The study was approved by the Ethics Committee of the Third Faculty of Medicine, Charles University.

\section{RESULTS}

\section{North Bohemia}

Baseline anthropometric and health characteristics of participants by gender are presented in Table 1. Significant differences in age, weight, height, and triceps skinfold thickness were observed between genders, while no significant differences in BMI, mid-arm, calf, and waist circumference were observed. Socio-demographic information is summarized in Table 2; $26 \%$ of respondents were immobile, $36.6 \%$ were ambulatory with assistance, and $37.4 \%$ were ambulatory without assistance. Mental status was normal in $51.2 \%$, while $15.8 \%$ suffered from severe depression or dementia. Most participants (91.3\%) were able to feed themselves. We found that $15.8 \%$ of women and $11.3 \%$ of men used nutritional supplements, which included multivitamins, calcium and vitamin D. No significant gender differences were observed between the use of nutritional supplements. Approximately half of the participants $(54.3 \%$ of women and $50.0 \%$ of men) were following a physician prescribed diet, with the most common being diabetes $(66.8 \%)$ or gallbladder $(22.1 \%)$ diets. Smoking was significantly more prevalent among males.

According to the MNA results, $38.8 \%$ of participants were well nourished, $50.8 \%$ were at risk of malnutrition, and $10.4 \%$ were found to be malnourished. The difference in malnutrition between men and women was significant in all three MNA categories (Table 3 ). MNA categories were positively correlated with independence $(\mathrm{r}=0.56 ; \mathrm{p}<0.001)$, mental status $(\mathrm{r}=0.54$; $\mathrm{p}<0.001)$, mobility $(\mathrm{r}=0.46 ; \mathrm{p}<0.001)$, calf circumference $(\mathrm{r}=0.42 ; \mathrm{p}<0.001)$, BMI $(\mathrm{r}=0.37 ; \mathrm{p}<0.001)$, and the ability to self-feed $(\mathrm{r}=0.37 ; \mathrm{p}<0.001)$. Most biochemical parameters were within reference limits, although they were correlated with worsening nutritional status. Serum albumin levels were $<28 \mathrm{~g} / 1$ in $10.3 \%$ of participants and $<35 \mathrm{~g} / 1$ in $30.3 \%$ of participants. Most $(82.7 \%)$ respondents with good nutritional status had normal values while only $34.6 \%$ ( 9 of 26) of those in the malnourished group (MNA score 2) had normal values. Normal prealbumin values were found in $66.2 \%$ (49 of 74) of well nourished seniors versus $50.0 \%$ (13 of 26 ) in MNA group 2. About one third of seniors $(28.7 \%)$ with prealbumin levels below the reference range were in MNA category 1 (i.e. at risk of malnutrition). Normal transferrin values were found in $66.2 \%$ (49 of 74) of well nour- 
Table 3. Proportions of institutionalized elderly participants from North Bohemia according to Mini-Nutritional Assessment $(M N A)$ categories $(N=254)$

\begin{tabular}{|l|c|c|c|c|}
\hline MNA Category & $\begin{array}{c}\text { Total } \\
\mathbf{N}=\mathbf{2 5 4}\end{array}$ & $\begin{array}{c}\text { Females } \\
\mathrm{n}=\mathbf{1 8 3}\end{array}$ & $\begin{array}{c}\text { Males } \\
\mathrm{n}=\mathbf{7 1}\end{array}$ & $\mathbf{p}$ \\
\hline Well nourished & 38.8 & 36.1 & 47.9 & 0.001 \\
\hline Risk of malnutrition & 50.8 & 51.9 & 45.1 & 0.05 \\
\hline Malnourished & 10.4 & 12.0 & 7.0 & 0.001 \\
\hline
\end{tabular}

ished seniors versus $29.2 \%$ ( 7 of 24 ) in MNA group 2. Very few elderly participants $(4.1 \%)$ had creatinine levels higher than the reference range and $12.8 \%$ of seniors had serum urea levels higher than the reference range. No significant difference in serum urea was found between the elderly with good nutritional status, and those who were malnourished (Table 4).

\section{Data Comparison - North Bohemia versus Prague}

When comparing the participating elderly from North Bohemia with those from Prague, significant differences were observed in the following criteria: age, BMI, MAC, CC, WC, and triceps skinfold thickness (Tables 5 and 6). Significant differences were also observed regarding the highest achieved level of education of participants from North Bohemia and Prague. A primary school education was the highest level for almost half (49.4\%) of those from North Bohemia compared to $27 \%$ of those from Prague; secondary school education was the highest level for $14.5 \%$ of the North Bohemia sample and $33.1 \%$ of the Prague sample; and a university education was the highest level for $3 \%$ of the North
Bohemia sample and $7 \%$ of the Prague sample. The North Bohemia sample included more single men $(28.3 \%)$ than the Prague sample $(15.5 \%)$. The ratio of widowed men and women was similar in both samples: North Bohemia men 48.3\% vs. Prague men 46.5\%; North Bohemia women $81.4 \%$ vs. Prague women $77.7 \%$. The percentage of divorced individuals was also similar. There were differences based on the type of previous employment between the two regions. The percentage of male manual labourers was higher in North Bohemia $(68.2 \%)$ compared to Prague $(43.9 \%)$, as was the percentage of female manual labourers in North Bohemia (63.4\%) vs. Prague (24.6\%). In North Bohemia, $14.7 \%$ of men and $18.9 \%$ of women were office workers, while in Prague $31.0 \%$ of men and $37.9 \%$ of women were office workers. There was a significant difference between former smokers and current smokers in both North Bohemia (12.0\% former vs. $15.1 \%$ current) and Prague (25.0\% former vs. $6.2 \%$ current). Significantly fewer respondents in North Bohemia took nutritional supplements (14.6\%) vs. Prague (29.0\%). More people were at risk of malnutrition in North Bohemia compared to Prague, and in Prague more respondents were well nourished compared to North Bohemia $(\mathrm{p}=0.006)$ (Table 7).

Table 4. Mean values of biochemical parameters in three categories based on Mini-Nutritional Assessment (MNA) results, institutionalized elderly participants from North Bohemia

\begin{tabular}{|c|c|c|c|c|c|c|c|c|}
\hline $\begin{array}{l}\text { Biochemical } \\
\text { parameters* }\end{array}$ & MNA & $n$ & Mean (SD) & Min. & Max. & $\begin{array}{c}<\text { Reference } \\
\text { values } \\
\mathrm{n}(\%)\end{array}$ & $\begin{array}{c}\text { Reference } \\
\text { values } \\
n(\%) \\
\end{array}$ & $p$ \\
\hline \multirow{3}{*}{$\begin{array}{l}\text { Albumin g/L } \\
35.0-50.0\end{array}$} & 0 & 75 & $37.5(5.14)$ & 21.4 & 46.5 & $13(17.3)$ & 62 (82.7) & $\mathrm{ns}^{\mathrm{a}}$ \\
\hline & 1 & 94 & $35.8(5.08)$ & 20.0 & 49.3 & $29(30.9)$ & 65 (69.1) & $0.05^{b}$ \\
\hline & 2 & 26 & $31.7(7.15)$ & 13.5 & 45.5 & $17(65.4)$ & $9(34.6)$ & $0.05^{c}$ \\
\hline \multirow{3}{*}{$\begin{array}{l}\text { Prealbumin } \mathrm{g} / \mathrm{L} \\
0.20-0.40\end{array}$} & 0 & 74 & $0.32(0.30)$ & 0.11 & 2.09 & $12(16.2)$ & $49(66.2)$ & $n s^{a}$ \\
\hline & 1 & 94 & $0.29(0.29)$ & 0.10 & 2.94 & $27(28.7)$ & $61(64.9)$ & $n s^{b}$ \\
\hline & 2 & 26 & $0.30(0.29)$ & 0.10 & 1.48 & $9(34.6)$ & $13(50.0)$ & $\mathrm{ns}^{\mathrm{c}}$ \\
\hline \multirow{3}{*}{$\begin{array}{l}\text { Transferrin g/L } \\
2.00-4.00\end{array}$} & 0 & 74 & $2.13(0.53)$ & 0.32 & 3.2 & $25(33.8)$ & $49(66.2)$ & $n s^{a}$ \\
\hline & 1 & 94 & $2.10(0.46)$ & 1.02 & 3.39 & $36(38.3)$ & 58 (61.7) & $0.05^{b}$ \\
\hline & 2 & 24 & $1.76(0.64)$ & 0.91 & 3.86 & $17(70.8)$ & $7(29.2)$ & $0.05^{c}$ \\
\hline \multirow{3}{*}{$\begin{array}{l}\text { Urea mmol/L } \\
2.83-8.35\end{array}$} & 0 & 75 & $6.50(2.14)$ & 2.4 & 13.1 & $1(1.3)$ & $62(82.7)$ & $n s^{a}$ \\
\hline & 1 & 94 & 6.19 (1.91) & 3.2 & 15.4 & 0 & $84(89.4)$ & $n s^{b}$ \\
\hline & 2 & 26 & $6.27(2.18)$ & 2.6 & 12.3 & $1(3.8)$ & $22(84.6)$ & $\mathrm{ns}^{\mathrm{c}}$ \\
\hline \multirow{3}{*}{$\begin{array}{l}\text { Creatinine } \\
\mu \mathrm{mol} / \mathrm{L} \\
71.0-133.0\end{array}$} & 0 & 75 & $87.5(34.2)$ & 29 & 212 & $25(33.3)$ & 44 (58.7) & $\mathrm{ns}^{\mathrm{a}}$ \\
\hline & 1 & 94 & $80.1(23.1)$ & 37 & 161 & $31(33.0)$ & $61(64.9)$ & $0.05^{b}$ \\
\hline & 2 & 26 & $67.9(21.1)$ & 24 & 115 & $16(61.5)$ & $10(38.5)$ & $0.05^{c}$ \\
\hline
\end{tabular}

ns $=$ not significant, $0=$ well nourished, $1=$ risk of malnutrition, $2=$ malnourished

asignificant differences between categories 0 and 1

bSignificant differences between categories 1 and 2

'Significant differences between categories 0 and 2

*Reference values $(11,12)$ 
Table 5. Comparison of anthropometric data and Mini-Nutritional Assessment (MNA) score between North Bohemia and Prague (9) (females)

\begin{tabular}{|l|c|c|c|}
\hline Anthropometric data in females & $\begin{array}{c}\text { North Bohemia } \\
\mathrm{n}=183 \\
\text { mean (SD) }\end{array}$ & $\begin{array}{c}\text { Prague } \\
\mathrm{n}=659 \\
\text { mean (SD) }\end{array}$ & $\mathrm{p}$ \\
\hline Age $($ years) & $80.8(8.05)$ & $86.1(6.15)$ & 0.001 \\
\hline BMI $\left(\mathrm{kg} / \mathrm{m}^{2}\right)$ & $27.4(5.95)$ & $25.5(5.21)$ & 0.001 \\
\hline Mid-arm circumference $(\mathrm{cm})$ & $28.5(4.39)$ & $25.9(3.72)$ & 0.001 \\
\hline Calf circumference $(\mathrm{cm})$ & $34.4(5.29)$ & $32.0(12.8)$ & 0.001 \\
\hline Triceps skinfold thickness $(\mathrm{mm})$ & $16.5(6.5)$ & $14.5(5.3)$ & 0.001 \\
\hline Waist circumference $(\mathrm{cm})$ & $98.0(13.4)$ & $88.9(17)$ & 0.001 \\
\hline MNA score & $22.7(3.76)$ & $23.5(3.76)$ & $\mathrm{ns}$ \\
\hline
\end{tabular}

Table 6. Comparison of anthropometric data and Mini-Nutritional Assessment (MNA) score between North Bohemia and Prague (9) (males)

\begin{tabular}{|l|c|c|c|}
\hline Anthropometric data in males & $\begin{array}{c}\text { North Bohemia } \\
\mathrm{n=71} \\
\text { mean (SD) }\end{array}$ & $\begin{array}{c}\text { Prague } \\
\mathrm{n}=156 \\
\text { mean (SD) }\end{array}$ & $\mathrm{p}$ \\
\hline Age (years) & $75.9(8.71)$ & $81.5(7.97)$ & 0.001 \\
\hline BMl $\left(\mathrm{kg} / \mathrm{m}^{2}\right)$ & $26.3(5.42)$ & $27.5(4.87)$ & $\mathrm{ns}$ \\
\hline Mid-arm circumference $(\mathrm{cm})$ & $28.5(3.77)$ & $26.6(3.14)$ & 0.001 \\
\hline Calf circumference $(\mathrm{cm})$ & $34.8(4.04)$ & $33.4(4.29)$ & 0.05 \\
\hline Triceps skinfold thickness $(\mathrm{mm})$ & $12.0(6.43)$ & $10.6(4.3)$ & 0.001 \\
\hline Waist circumference $(\mathrm{cm})$ & $102.9(13.6)$ & $95.1(19.1)$ & 0.05 \\
\hline MNA score & $23.0(2.82)$ & $24.4(3.35)$ & 0.05 \\
\hline
\end{tabular}

Table 7. Comparison of Mini-Nutritional Assessment (MNA) results (\%) for institutionalized elderly participants in North Bohemia and Prague (9)

\begin{tabular}{|l|c|c|c|}
\hline MNA Category & $\begin{array}{c}\text { North Bohemia } \\
\mathrm{n}=\mathbf{2 5 4}\end{array}$ & $\begin{array}{c}\text { Prague } \\
\mathrm{n}=815\end{array}$ \\
\hline Well nourished & 38.8 & 50.4 & $\mathrm{p}$ \\
\hline Risk of malnutrition & 50.8 & 39.4 & 0.006 \\
\hline Malnourished & 10.4 & 10.2 & 0.006 \\
\hline
\end{tabular}

\section{DISCUSSION}

Since its validation in 1994, the MNA has been used in hundreds of studies (13). Many other studies have found a higher prevalence of malnutrition than supported by our study. A group of studies confirmed the presence of malnutrition based on MNA items that range from $25-60 \%$ (14). According to the results published by Saletti (15), one third of study participants residing in assistedliving accommodations and more than one half of those living in nursing homes appeared to be malnourished. Similar results have been found in other countries: in Japan, $19.9 \%$ of participants were malnourished (16), as were $29 \%$ in Finland (17), 37.8\% in Austria (18), 36\% in Italy (19), and $17.7 \%$ in Sweden. Interestingly, Sweden also had $40.3 \%$ of the institutionalized elderly at risk of malnutrition, and only $41.6 \%$ were well nourished according to the MNA (20). In our study, MNA scores were associated with specific anthropometric characteristics. This association has also been confirmed by other authors in terms of age, weight and BMI (21), mid-arm circumference and calf circumference (6), triceps skinfold thickness (22), and waist circumference in conjunction with other factors such as mental status and mobility (23). MNA results correlate with clinical screening and objective indicators of nutritional status such as albumin (3), energy, and vitamin intake $(3,5)$. In our study, MNA categories were positively correlated with independence, mental status, mobility, calf circumference, and ability to self-feed. Age was correlated with MNA scores and BMI, which was similar to a study by Saletti et al. (15). We also confirmed that significantly larger proportion of women were malnourished than men, which has also been reported in studies from other countries $(17,21)$. A French study showed that having been widowed is significantly associated with a poorer nutritional status (21). In addition, other authors have shown that marital status, specifically being widowed, is also associated with a poorer nutritional status (24). According to Montejano et al. (25), a feeling of loneliness is one factor associated with an increased risk of malnutrition, and feelings of loneliness are more common in widowed persons compared to those with a companion or partner. Despite the studies mentioned above, no difference was found 
in widowed marital status between our two samples, however, there was a difference with the proportion of single respondents.

The laboratory malnutrition reports indicated a decrease in serum proteins (albumin, transferrin, and prealbumin). A study from Hradec Kralove, an averaged-sized town in the central part of the Czech Republic, found low levels of albumin (less than $28 \mathrm{~g} / \mathrm{l}$ ) in $13.5 \%$ of the elderly population during (non-surgical) hospital admissions and $66 \%$ of (surgical) hospital admissions (26). In a study by Rambousková et al. (27), 30\% of Czech patients older than 75 years who were admitted to hospital had biochemical markers indicative of reduced protein synthesis. Albumin values $<28 \mathrm{~g} / \mathrm{l}$ were found in $34.1 \%$ of patients arriving from retirement facilities compared to $22.3 \%$ of patients admitted from a personal residence. Omran and Morley (28) assessed blood urea and creatinine and found that plasma urea levels often reflected protein catabolism. These values tend to rise during malnutrition. Lower values of creatinine are common in people with reduced muscle mass and are associated with prolonged periods of being bed-ridden. This trend was also observed in our group of elderly participants.

In 2014, Torres et al. (21) compared the nutritional status of the elderly individuals residing at home in rural vs. urban areas; $7.4 \%$ of participants in rural areas were found to have poor nutritional status, while the same status was observed in $18.5 \%$ of those in urban areas. Contrary to our results, Torres et al. found that the frequency of malnourishment appeared to be more than twice as high in the urban sample (21). In our study, three towns from North Bohemia were used to represent a population that was more rural compared to Prague. However, it is important to note that while North Bohemia is more rural than Prague it is also more industrialized, which may explain the conflicting results compared with the Torres' study.

Individual characteristics that influence the nutritional status of elderly living in a community setting are poorly understood (e.g. living in rural or urban areas in the same country or industrial vs. non-industrial, or variations). It is possible that these variables could influence lifestyle and food availability (29). Participants from North Bohemia had lower levels of education and had a history of manual labour compared to the Prague group, with both factors being associated with a higher risk of malnutrition. Lower education levels are positively correlated with increased risk of malnutrition (30) as is the absence of a university education (25).

The study was limited by a small number of participants and a limited number of retirement homes from one region of North Bohemia. Blood samples were analysed in fewer respondents due to refusal of blood sampling by some study participants. Further research comparing the institutionalized elderly nutritional status with their eating habits is needed in the future to clarify the causes of malnutrition in the elderly.

\section{CONCLUSION}

This study describes the nutritional status of elderly residents living in three retirement homes in North Bohemia and compares the results with the elderly living in similar facilities in Prague. The study measured anthropometric and biochemical indicators of nutritional status. Biochemical indicators supported the nutritional status as classified by MNA testing. MNA testing easily and reliably identifies the institutionalized elderly that are at risk of malnutrition. It also provides a method for early and effective nutritional intervention as well as identifying those who may require higher levels of care. Our results should contribute to better and more effective prevention of nutritional deficits in the elderly population, in particular, the institutionalized elderly population. The early detection of malnutrition in old age can prevent deterioration of functional performance. The identification of individuals that are at risk of malnutrition followed by appropriate interventions can improve nutritional status and physical functions, reduce complications associated with pre-existing conditions, and speed recovery from illnesses. As such, it is an important component of health care. Malnutrition screening should be a routine assessment for the elderly, especially for those at increased risk, i.e., those residing in hospitals and nursing homes.

\section{Conflict of Interests}

None declared

\section{Acknowledgements}

The study was supported by the research grant IGA MZ ČR No NS 9972-4/2008 and PROGRES Q36. The authors would like to thank the participating retirement homes and the residents for their cooperation, and Thomas Secrest and Carl Maynard for language editing.

\section{REFERENCES}

1. Stratton RJ, Green CJ, Elia M. Disease-related malnutrition: an evidence based approach to treatment. Wallingford: CABI Publishing; 2003.

2. Hirose T, Hasegawa J, Izawa S, Enoki H, Suzuki Y, Kuzuya M. Accumulation of geriatric conditions is associated with poor nutritional status in dependent older people living in the community and in nursing homes. Geriatr Gerontol Int. 2014;14(1):198-205.

3. Guigoz Y, Vellas BJ. Malnutrition in the elderly: the mini nutritional assessment. Ther Umsch. 1997;54(6):345-50. (In German.)

4. Wyka J, Biernat J, Mikolajczak J, Piotrowska E. Assessment of Dietary Intake and Nutritional Status (MNA) in Polish Free-living Elderly People from Rural Environments. Arch Gerontol Geriatr. 2012;54(1):44-9.

5. Stange I, Poeschl K, Stehle P, Sieber CC, Volkert D. Screening for malnutrition in nursing home residents: comparison of different risk markers and their association to functional impairment. J Nutr Health Aging. 2013;17(4):357-63.

6. Chavarro-Carvajal D, Reyes-Ortiz C, Samper-Ternent R, Arciniegas AJ, Gutierrez CC. Nutritional assessment and factors associated to malnutrition in older adults: a cross-sectional study in Bogotá, Colombia. J Aging Health. 2015;27(2):304-19.

7. Mowe M, Bohmer T, Kindt E. Reduced nutritional status in an elderly population $(>70 \mathrm{y})$ is probable before disease and possibly contributes to the development of disease. Am J Clin Nutr. 1994;59(2):317-24.

8. Bauer JM, Sieber CC. Significance and diagnosis of malnutrition in the elderly. Z Arztl Fortbild Qualitätssich. 2007;101(9):605-9. (In German.)

9. Rambousková J, Slavíková M, Krsková A, Procházka B, Anděl M, Dlouhý P. Nutritional status assessment of institutionalized elderly in Prague, Czech Republic. Ann Nutr Metab. 2013;62(3):201-6.

10. Vellas B, Guigoz Y, Garry PJ, Nourhashemi F, Bennahum D, Lauque S, et al. The Mini Nutritional Assessment (MNA) and its use in grading the nutritional state of elderly patients. Nutrition. 1999;15(2):116-22.

11. Ritchie RF, Navolotskaia O, editors. Serum proteins in clinical medicine. Vol. 1, Laboratory section. Scarborough: Foundation for blood Research; 1996.

12. Tietz NW, editor. Clinical guide to laboratory tests. 3rd ed. Philadelphia: W.B. Saunders Company; 1995.

13. Vellas B, Villars H, Abellan G, Soto ME, Rolland Y, Guigoz Y, et al. Overview of the MNA-Its history and challenges. J Nutr Health Aging. 2006;10(6):456-63.

14. Antonelli Incalzi R, Landi F, Cipriani L, Bruno E, Pagano F, Gemma A, et al. Nutritional assessment: a primary component of multidimen- 
sional geriatric assessment in the acute care setting. J Am Geriatr Soc. 1996;44(2):166-74.

15. Saletti A, Lindgren EY, Johansson L, Cederholm T. Nutritional status according to mini nutritional assessment in an institutionalized elderly population in Sweden. Gerontology. 2000;46(3):139-45.

16. Kuzuya M, Kanda S, Koike T, Suzuki Y, Satake S, Iguchi A. Evaluation of Mini-Nutritional Assessment for Japanese frail elderly. Nutrition. 2005;21(4):498-503.

17. Suominen M, Muurinen S, Routasalo P, Soini H, Suur-Uski I, Peiponen A, et al. Malnutrition and associated factors among aged residents in all nursing homes in Helsinki. Eur J Clin Nutr. 2005;59(4):578-83.

18. Kulnik D, Elmadfa I. Assessment of the nutritional situation of elderly nursing home residents in Vienna. Ann Nutr Metab. 2008;52 Suppl 1:51-3.

19. Donini LM, Neri B, De Chiara S, Poggiogalle E, Muscaritoli M. Nutritional care in a nursing home in Italy. PLoS One. 2013;8(2):e55804. doi: 10.1371/journal.pone.0055804.

20. Borgström Bolmsjö B, Jakobsson U, Mölstad S, Ostgren CJ, Midlöv P. The nutritional situation in Swedish nursing homes - a longitudinal study. Arch Gerontol Geriatr. 2015;60(1):128-33

21. Torres MJ, Dorigny B, Kuhn M, Berr C, Barberger-Gateau P, Letenneu L. Nutritional status in community-dwelling elderly in France in urban and rural areas. PloS One. 2014;9(8):e105137. doi: 10.1371/journal. pone. 0105137 .

22. Siebens H, Trupe E, Siebens A, Cook F, Anshen S, Hanauer R, et al. Correlates and consequences of eating dependency in institutionalized elderly. J Am Geriatr Soc. 1986;34(3):192-8.
23. Arvanitakis M, Vandewoude M, Perkisas S, Van Gossum A. Undernutrition in community dwelling elderly. ESPEN J. 2013;8(5):e213-5.

24. Brownie $\mathrm{S}$. Why are elderly individuals at risk of nutritional deficiency? Int J Nurs Pract. 2006;12(2):110-8.

25. Montejano Lozoya AR, Ferrer Diego RM, Clemente Marín G, MartínezAlzamora N, Sanjuan Quiles A, Ferrer Ferrándiz E. Nutrition-related risk factors in autonomous non-institutionalized adult elderly people. Nutr Hosp. 2014;30(4):858-69. (In Spanish.)

26. Hrnčiariková D, Zadák Z, Klemera P, Špirková J. The values of total protein and albumin in geriatric patients hospitalized at Univesity Hospital in Hradec Králové. Geriatria. 2007;13(1):12-6. (In Czech.)

27. Rambousková J, Křrižová E, Dlouhý P, Potočková J, Anděl M. Nutritional status in elderly people living in retirement homes in the Czech Republic. Hygiea Internationalis. 2010;9(1):375-83.

28. Omran ML, Morley JE. Assessment of protein energy malnutrition in older persons, Part II: Laboratory Evaluation. Nutrition. 2000;16(2):131-40.

29. National Center for Health Statistics. Health, United States, 2001: urban and rural health chartbook. Hyattsville, MD: National Center for Health Statistics; 2001

30. Ramage-Morin PL, Garriguet D. Nutritional risk among older Canadians. Health Rep. 2013;24(3):3-13.

Received October 7, 2016 Accepted in revised form May 13, 2018 